\title{
Changes of diazotrophic communities in response to cropping systems in a Mollisol of Northeast China
}

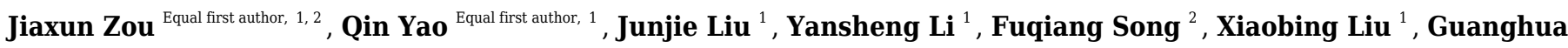 \\ Wang ${ }^{\text {Corresp. } 1}$ \\ ${ }^{1}$ Key Laboratory of Mollisols Agroecology, Northeast Institute of Geography and Agroecology, Chinese Academy of Sciences, Harbin, China \\ 2 College of Life Science, Heilongjiang University, Harbin, China \\ Corresponding Author: Guanghua Wang \\ Email address: wanggh@iga.ac.cn
}

Nitrogen-fixing microorganisms play important roles in $\mathrm{N}$ cycling. However, knowledge related to the changes in the diazotrophic community in response to cropping systems is still rudimentary. In this study, the nifH gene was used to reveal the abundance and community compositions of diazotrophs in the cropping systems of continuous cropping of corn (CC) and soybean (SS), and soybean-corn rotation for growing corn (CSC) and soybean (SCS) in a black soil of Northeast China. The results showed that the abundance of the nifH gene was significantly higher in cropping soybean than in cropping corn under the same cropping system, while remarkably increased in the rotation system under the same crop. The Shannon index in the CC treatment was significantly higher than that in the other treatments, but the OTU number and Chaol index had no significant change among the four treatments. Bradyrhizobium japonicum was the dominant diazotrophic species, and its relative abundance was at the lowest value in the CC treatment. In contrast, Skermanella sp. had the highest relative abundance in the CC treatment. A PCoA showed that the diazotrophic communities were separated between different cropping systems, and the variation caused by continuous corn cropping was the largest. Among the tested soil properties, the soil available phosphorus was a primary factor in determining diazotrophic community compositions. Overall, the findings of this study highlighted that the diazotrophic communities in black soils are very sensitive to cropping systems. 
1 Title: Changes of diazotrophic communities in response to cropping systems in a Mollisol of

2 Northeast China

3 Author names: Jiaxun Zou ${ }^{1,2, \dagger}$, Qin $\mathrm{Yao}^{1, \dagger}$, Junjie Liu ${ }^{1}$, Yansheng $\mathrm{Li}^{1}$, Fuqiang Song ${ }^{2}$, Xiaobing

4 Liu $^{1}$, Guanghua Wang ${ }^{1, *}$

6 Affiliation:

7 1. Key Laboratory of Mollisols Agroecology, Northeast Institute of Geography and Agroecology,

8 Chinese Academy of Sciences, Harbin 150081, China

9 2. College of Life Science, Heilongjiang University, Harbin 150080, China

$10 \uparrow$ These authors contributed equally to this work

11

12 * Corresponding author:

13 Guanghua Wang

14 No.138 Haping Road, Harbin, Heilongjiang, 150081, China

15 E-mail address: wanggh@iga.ac.cn 
16 Abstract: Nitrogen-fixing microorganisms play important roles in $\mathrm{N}$ cycling. However, knowledge related

17 to the changes in the diazotrophic community in response to cropping systems is still rudimentary. In this

18 study, the nifH gene was used to reveal the abundance and community compositions of diazotrophs in the

19 cropping systems of continuous cropping of corn (CC) and soybean (SS), and soybean-corn rotation for

20 growing corn (CSC) and soybean (SCS) in a black soil of Northeast China. The results showed that the

21 abundance of the nifH gene was significantly higher in cropping soybean than in cropping corn under the

22 same cropping system, while remarkably increased in the rotation system under the same crop. The Shannon

23 index in the $\mathrm{CC}$ treatment was significantly higher than that in the other treatments, but the OTU number

24 and Chao1 index had no significant change among the four treatments. Bradyrhizobium japonicum was the

25 dominant diazotrophic species, and its relative abundance was at the lowest value in the CC treatment. In

26 contrast, Skermanella sp. had the highest relative abundance in the CC treatment. A PCoA showed that the

27 diazotrophic communities were separated between different cropping systems, and the variation caused by

28 continuous corn cropping was the largest. Among the tested soil properties, the soil available phosphorus

29 was a primary factor in determining diazotrophic community compositions. Overall, the findings of this

30 study highlighted that the diazotrophic communities in black soils are very sensitive to cropping systems.

\section{1. Introduction}

The black soil zone of Northeast China is one of the four large Mollisol regions in the world and plays an important role in maintaining food security in China (Liu et al., 2008). In this region, soybean and corn

34 are two major crops that are either continuously cropped or grown annually in rotation with each other. It 
35 is well known that continuous cropping can decline soil quality, which seriously decreases the quantity and

36 quality of crop products. Previous studies have shown that continuous cropping has led to several problems

37 in soils, for example, deficiencies in soil nutrition (Ashworth et al., 2018), decreases in soil enzyme activity

38 (Chavarría et al., 2016), increases in the autotoxicity of root exudates (Huang et al., 2013), increases in

39 pests and diseases (Torres et al., 2018) and imbalances in soil microbial communities (Bennett et al., 2012).

40 Although the problems caused by continuous cropping of corn is less harmful than that of continuous

41 cropping of soybean (Xu et al., 2004), several studies have revealed that continuous cropping of corn has

42 caused the lodging and surge of pests, which have damaged corn yield (Jirak-Peterson \& Esker, 2011; Liang

et al., 2017). The cause of the barriers of continuous cropping are very complex, and some biotic and abiotic

factors are commonly related to crop-yielding decline. Among these factors, biotic factors, such as changes

in soil microbial communities, are often considered to be the major reason for barriers to continuous

cropping (Dias et al., 2015). Several studies have shown that continuous cropping destroyed the intrinsic

balance of soil microorganisms and increased abundance of crop pathogens such as soil-borne Fusarium

spp. (Xiong et al., 2015; Zhu et al., 2018).

Biological nitrogen fixation $(\mathrm{BNF})$ is the main route of inputting nitrogen $(\mathrm{N})$ in natural ecosystems.

Approximately 52-130 $\mathrm{Tg}$ of $\mathrm{N}$ is input into terrestrial ecosystems annually through the BNF method

51 (Davies-Barnard \& Friedlingstein, 2020). BNF is carried out by a wide range of microorganisms containing

52 nitrogen-fixing enzymes. The enzymes are regulated by multiple genes, and the nifH gene is one of the 
55 shown that the diazotrophic community is highly sensitive to variations in soil factors such as $\mathrm{pH}$ (Fan et

56 al., 2018), organic matter (Calderoli et al., 2017) and available nutrient content (Collavino et al., 2014).

57 Since soil factors are greatly affected by different cropping systems (Jha et al., 2004; Moisander et al.,

58 2012), whether different cropping systems have a direct or indirect impact on diazotrophic communities in

59 soils, especially in black soils, is rarely reported.

60 Using molecular fingerprinting methods, such as polymerase chain reaction-denaturing gradient gel

61 electrophoresis (PCR-DGGE) and the terminal restriction fragment length polymorphism (T-RFLP)

62 method, several studies have investigated the changes in diazotrophic communities in response to cropping

63 systems. For example, Silva et al. (2013) revealed that $\mathrm{NH}_{4}{ }^{+}-\mathrm{N}, \mathrm{NO}_{3}^{-}-\mathrm{N}$, and soil $\mathrm{pH}$ were the determining

64 factors in shifting the diazotrophic community structure by using the PCR-DGGE method. Using the T-

65 RFLP method, Xiao et al. (2010) revealed that diazotrophic community diversity in continuous cropping

66 of soybean fields was different from that in rotational cropping. However, the low resolutions of molecular

67 fingerprinting methods restricted in-depth data analysis and did not allow us to fully understand the changes

68 in diazotrophic community structures. Recently, high-throughput sequencing (HTS) has become the

69 mainstream method for studying diazotrophic communities (Wang et al., 2017; Hu et al., 2018). Using this

70 method, Wang et al. (2017) revealed that soil $\mathrm{pH}$ and nutrient availability had a cooperative effect on

71 diazotroph abundance, while soil nutrient availability was the main factor. Noticeably, most studies of using

72 HTS method to analyze the changes in microbial community structures in response to different cropping

73 systems have mainly focused on bacterial and fungal communities (Bai et al., 2015; Liu et al., 2017), rarely

74 specifically related to the diazotrophic community. 
75 In this study, we comparatively investigated the abundance, diversity and community structures of

76 diazotrophs under different cropping systems in the black soil region of Northeast China using real-time

77 PCR and Illumina MiSeq sequencing methods. Specifically, the purposes of this study were 1) to compare

78 the effect of different cropping systems on soil chemical properties; 2) to assess the responses of

79 diazotrophic abundance and diversity to different cropping systems; and 3) to examine the contributions of

80 crop types and soil factors to the changes of diazotrophic community structures.

\section{2. Materials and methods}

$82 \quad 2.1$ Study site descriptions and soil sampling

83 A fixed experimental field was established in 2013 at Guangrong Village ( $\left.47^{\circ} 21^{\prime} \mathrm{N}, 126^{\circ} 49^{\prime} \mathrm{E}\right)$, Hailun

84 County, Heilongjiang Province of Northeast China, to evaluate the long-term effectiveness of crop rotation

85 and continuous cropping systems. At the experimental site, the annual mean temperature and precipitation

86 were $1.5^{\circ} \mathrm{C}$ and $530 \mathrm{~mm}$, respectively. The soil in the experimental site was a typical black soil, which

87 classified as Mollisol according to the USA's soil taxonomy.

88 Four cropping treatments were evaluated in this study: continuously cropped corn (CC), continuously

89 cropped soybean (SS), soybean-corn rotation for growing corn crops (CSC) and soybean-corn rotation for

90 growing soybean crops (SCS) at the study year. The cropping sequences for the four treatments from the

91 starting year of 2013 to the sampling year of 2017 is shown in Fig. S1. Commercial fertilizers urea,

92 diammonium phosphate, and potassium sulfate were used as $\mathrm{N}, \mathrm{P}$ and $\mathrm{K}$ sources. The dosage of chemical

93 fertilizers used for growing soybean and corn was based on the local farming practice. For cropping

Peer] reviewing PDF | (2019:12:44497:2:1:NEW 11 Jun 2020) 
94 soybean, chemical fertilizers were applied before sowing at the rate of $35.2 \mathrm{~kg} \mathrm{P} \mathrm{ha}^{-1}, 55.2 \mathrm{~kg} \mathrm{~N} \mathrm{ha}^{-1}$ and

$9522.4 \mathrm{~kg} \mathrm{~K} \mathrm{ha}^{-1}$. For cropping corn, chemical fertilizers were supplied before sowing as base fertilizers at the

96 rate of $35.2 \mathrm{~kg} \mathrm{P} \mathrm{ha}^{-1}, 66.9 \mathrm{~kg} \mathrm{~N} \mathrm{ha}^{-1}$ and $22.4 \mathrm{~kg} \mathrm{~K} \mathrm{ha}^{-1}$. Additionally, $105 \mathrm{~kg} \mathrm{~N} \mathrm{ha}^{-1}$ was supplied as top

97 dressing at the V6 stage (6th leaf collars visible) of corn.

98 Each treatment had four randomly arranged replicate plots, and each plot was $75.6 \mathrm{~m}^{2}$ containing 12 rows

99 with a row length of $9 \mathrm{~m}$ and width of $70 \mathrm{~cm}$. Soil samples were collected on 14 September 2017 from the

100 field when soybean was nearly at maturity (R7 stage) and corn was at wax maturity. From each plot, five

101 points of soil within a depth of 0-20 cm were randomly collected and combined into a single sample. The

102 soil was placed into individual sterile plastic bags, which were placed in ice boxes and transferred back to

103 the laboratory immediately. At the laboratory, the soil was sieved through a 2-mm mesh and divided into

104 two parts: one part was stored at $-80{ }^{\circ} \mathrm{C}$ for DNA extraction, and the remaining soil was kept at $4{ }^{\circ} \mathrm{C}$ for

105 soil chemical analysis.

1062.2 Soil chemical property analysis

107 Soil $\mathrm{pH}$ was determined using a $\mathrm{pH}$ meter in the soil-water suspension $(1: 2.5 \mathrm{w} / \mathrm{v})$. The concentrations

108 of soil total carbon (TC) and total nitrogen (TN) were determined using an elemental analyzer (VarioEL

109 III, Germany). Soil $\mathrm{NH}_{4}{ }^{+}-\mathrm{N}$ and $\mathrm{NO}_{3}{ }^{-}-\mathrm{N}$ extracted with $2.0 \mathrm{M} \mathrm{KCl}$ solution, total phosphorus (TP) digested

110 by $\mathrm{HClO}_{4}-\mathrm{H}_{2} \mathrm{SO}_{4}$ and available phosphorus (AP) extracted with $\mathrm{NaHCO}_{3}$ were measured with a continuous

111 flow analytical system (SKALAR SAN++, The Netherlands). Soil total potassium (TK) digested with

$112 \mathrm{HNO}_{3}-\mathrm{HClO}_{4}-\mathrm{HF}$ and available potassium (AK) extracted with $1.0 \mathrm{M} \mathrm{NH}_{4} \mathrm{Ac}$ were estimated using 
113 inductively coupled plasma-atomic emission spectrometry (ICPS-7500, Shimadzu, Japan) (Lu, 2000).

114 2.3 Soil DNA extractions and quantification of nifH gene abundance

115 The total soil DNA of each sample was extracted from $0.5 \mathrm{~g}$ of soil samples kept in $-80{ }^{\circ} \mathrm{C}$ freezer using

116 a FastDNA ${ }^{\circledR}$ SPIN Kit for Soil (MP Biomedicals, Santa Ana, CA, USA) following the manufacturer's

117 protocols. The extracted DNA was diluted in DES buffer (DNA Elution Solution-Ultra Pure Water). DNA

118 concentration was determined with the NanoDrop method (NanoDrop 2000, Thermo Scientific, USA) and

119 then stored at $-20^{\circ} \mathrm{C}$ until further use.

120 Quantitative real-time PCR (qPCR) was performed using the primers nifH-F (5'-AAA GGY GGW ATC

121 GGY AAR TCCA CCA C-3') and nifH-R (5'-TTG TTS GCS GCR TAC ATS GCC ATC AT-3') to measure

122 the abundance of the nifH gene in a LightCycler ${ }^{\circledR} 480$ (Roche Applied Science, Basel, Switzerland). Each

123 qPCR reaction mixture contained $10 \mu \mathrm{L}$ of SYBR Premix Ex TaqTM (Takara, Dalian, China), $1 \mu \mathrm{L}$ of

124 extracted soil DNA, $1 \mu \mathrm{L}$ of $10 \mu \mathrm{M}$ forward primer, $1 \mu \mathrm{L}$ of $10 \mu \mathrm{M}$ reverse primer and $7.0 \mu \mathrm{L}$ of sterilized

125 MilliQ water (Rösch et al., 2002). For each sample, qPCR amplification was performed in triplicate

126 following a program of denaturation at $95{ }^{\circ} \mathrm{C}$ for $30 \mathrm{~s}$ (ramp rate of $4.4{ }^{\circ} \mathrm{C} / \mathrm{s}$ ), 30 amplification cycles of 95

$127{ }^{\circ} \mathrm{C}$ for $5 \mathrm{~s}, 60^{\circ} \mathrm{C}$ for $30 \mathrm{~s}$ and $50^{\circ} \mathrm{C}$ for $30 \mathrm{~s}$. The nifH gene copy numbers were calculated using a regression

128 equation for converting the cycle threshold $\left(C_{\mathrm{t}}\right)$ value to the known number of cloned nifH gene ranged

129 from $5.07 \times 10^{2}$ to $5.07 \times 10^{8}$ gene copies per $\mu \mathrm{L}$ in the standards (Hu et al., 2018). 
130 2.4 Illumina MiSeq sequencing

131 The diazotrophic community was analyzed using the $n i f H$ gene-specific primers $n i f H-\mathrm{F} / n i f H-\mathrm{R}$ with 7-

132 bp unique barcodes at the $5^{\prime}$ end, which produced an approximately 432 bp PCR product. The PCRs were

133 performed in triplicate for each sample in ABI GeneAmp ${ }^{\circledR} 9700$ with a volume of $20 \mu \mathrm{L}$, which comprised

$1344 \mu \mathrm{L}$ of $5 \times$ FastPfu Buffer, $2 \mu \mathrm{L}$ of $2.5 \mathrm{mM}$ dNTPs, $0.8 \mu \mathrm{L}(5 \mu \mathrm{M})$ of each primer, $0.4 \mu \mathrm{L}$ of FastPfu

135 Polymerase, $0.2 \mu \mathrm{L}$ of BSA (Bovine Serum Albumin) solution, $1.0 \mu \mathrm{L}$ of template DNA (10 ng) and dd $\mathrm{H}_{2} \mathrm{O}$

136 to reach $20 \mu \mathrm{L}$. The PCR amplification program started with $95{ }^{\circ} \mathrm{C}$ for $3 \mathrm{~min}$ for initial denaturation,

137 followed by 35 cycles of $95{ }^{\circ} \mathrm{C}$ for $30 \mathrm{~s}$ for denaturation, $55{ }^{\circ} \mathrm{C}$ for $30 \mathrm{~s}$ for annealing, $72{ }^{\circ} \mathrm{C}$ for $45 \mathrm{~s}$, and

138 ended with one final cycle at $72{ }^{\circ} \mathrm{C}$ for $10 \mathrm{~min}$ for extension. Equimolar amounts of the purified PCR

139 products were pooled and paired-end sequenced on an Illumina MiSeq platform at Majorbio BioPharm

140 Technology Co., Ltd., Shanghai, China.

1412.5 Sequence data analysis

142 After sequencing, QIIME Pipeline (Version 1.9.0) was used to process the raw data

143 (http://qiime.org/tutorials/tutorial.html) (Caporaso et al., 2010). Sequences shorter than 200 bp or with an

144 average base quality score below 20 were removed before further analysis. Removal of the trimmed

145 sequences was done with the UCHIME algorithm (Edgar et al., 2011). Clustering of the high-quality

146 sequences into operational taxonomic units (OTUs) was performed through the UPARSE software

147 (http://drive5.com/uparse/) at a 97\% similarity level. Representative sequences from each OTU were

148 translated into amino acid sequences and taxonomic identification was performed using a BLASTp search

149 tool at the NCBI website (https://blast.ncbi.nlm.nih.gov/). Visualization of microbial communities at the 
150 OTU level in different samples was conducted using Circos (Krzywinski et al., 2009). All raw sequences

151 generated in this study have been deposited in NCBI under the accession PRJNA516581.

152 2.6 Statistical analysis

153 To compare the difference between samples, the lowest sequence number of 6545 was randomly selected

154 from each sample as subset data for diazotrophic diversity analyses. The alpha diversity of diazotrophic

155 community was presented by Shannon, Simpson, OTU number and Chao1 indices. SPSS software (Version

156 22.0) was used to evaluate the significant differences in soil properties, diazotrophic abundance and alpha

157 diversity between treatments by one-way ANOVA analysis, as well as to calculate the correlations between

158 the community compositions of diazotroph and soil properties. Based on a UniFrac distance matrix, the

159 beta diversity of diazotrophic community was analyzed through principal coordinate analysis (PCoA) in

160 the R environment (version 3.2.5) (R Development Core Team, 2016). The difference in the diazotrophic

161 community between treatments was analyzed using the Adonis method based on Bray-Curtis distances

162 (Clarke et al., 1993), which was conducted using the "vegan" library in the R environment. The

163 relationships between the soil properties and composition of the diazotrophic community were analyzed by

164 Redundancy Analysis (RDA) and envfit analysis in the R environment using the "vegan" library.

\section{3. Results}

166 3.1 Changes of soil properties

167 The effects of different cropping systems on soil chemical properties are summarized in Table 1. The

168 soil $\mathrm{pH}, \mathrm{TK}, \mathrm{AK}$ and $\mathrm{TC}$ contents were not significantly changed among the treatments. The AP content 
169 varied significantly among treatments $(P<0.05)$, with the highest and the lowest values in the SCS and CC

170 treatments, respectively. $\mathrm{C} / \mathrm{N}$ was significantly higher in the $\mathrm{CC}$ and SS treatments than in the CSC and

171 SCS treatments $(P<0.05)$. The contents of soil $\mathrm{TN}, \mathrm{NH}_{4}{ }^{+}-\mathrm{N}$ and $\mathrm{NO}_{3}{ }^{-}-\mathrm{N}$ were significantly changed among

172 the treatments $(P<0.05)$, with the highest values in the CSC treatment. Overall, this result indicated that

173 different cropping systems significantly changed the soil nutrient content, especially the chemical properties

174 related to nitrogen nutrition.

1753.2 Abundance of the nifH gene

176 The abundance of the nifH gene varied significantly among treatments $(P<0.01)$, and it ranged from an

177 average of $2.3 \times 10^{6}$ to $11.1 \times 10^{6}$ gene copies per gram of soil under different cropping systems (Fig. 1A).

178 The abundance of the $n i f H$ gene in the SCS treatment was $57.4 \%, 123.8 \%$ and $382.3 \%$ higher compared to

179 that in SS, CSC and CC, respectively. Pearson's correlation analysis showed that nifH gene abundance was

180 significantly correlated with $\mathrm{C} / \mathrm{N}(r=-0.541, P=0.031), \mathrm{NO}_{3}^{-}-\mathrm{N}(r=-0.602, P=0.014)$, and AP $(r=0.597$,

$181 P=0.015)($ Fig. 1B, C, D).

1823.3 Alpha diversity index of the diazotrophic community

183 The alpha diversity of the diazotrophic community showed that the Shannon and Simpson indices had

184 opposite results. CC treatment had the highest score with Shannon index but had the lowest score with

185 Simpson index. The OTU numbers and Chao1 values were not significantly different among treatments

186 (Fig. 2). Pearson's correlation analysis showed that the Shannon index had a significant positive correlation

187 with $\mathrm{C} / \mathrm{N}(r=0.517, P=0.040)$ and a significant negative correlation with $\mathrm{AP}(r=-0.664, P=0.005)$. In 
188 contrast, the Simpson index showed the opposite trend (Table 2).

189 3.4 Diazotrophic community composition

190 A total of 205,696 high quality sequences were obtained across all samples, with an average of 12,853

191 sequences per sample. A random subset of 6545 (minimum number of sequences) sequences was selected

192 from each sample for downstream analysis. Proteobacteria was the dominant phylum in all treatments, with

193 average relative abundances ranging from $99.91 \%$ to $100 \%$ across four treatments. Within this phylum, the

194 Alphaproteobacteria was the dominant class, with an average relative abundance ranging from $94.35 \%$ to

$19596.13 \%$, while the highest relative abundances of Betaproteobacteria and Deltaproteobacteria were only

$1961.37 \%$ and $1.71 \%$, respectively. In addition, a very low abundance of Cyanobacteria was detected in some

197 samples (Table 3).

198 At the order level, six groups, Burkholderiales, Desulfuromomadales, Myxococcales, Nostocales,

199 Rhizobiales and Rhodospirillales were detected across all samples (Table 3). Among them, Rhizobiales

200 was the dominant order, with an average relative abundance ranging from $81.97 \%$ to $92.47 \%$ across four

201 treatments. Rhodospirillales was the second most abundant order, with average relative abundance ranging

202 from $2.09 \%$ to $10.09 \%$. The other orders had very lower abundances. Contrary to Rhizobiales,

203 Rhodospirillales was significantly $(P<0.05)$ more abundant in the $\mathrm{CC}$ treatment.

204 At the family level, Bradyrhizobiaceae and Rhodospirillaceae were the two most abundant diazotrophs, 205 and their average relative abundances ranged from $63.20 \%$ to $87.25 \%$ and from $2.09 \%$ to $10.09 \%$ across

206 treatments, respectively (Table 3). Contrasting with Rhodospirillaceae, Bradyrhizobiaceae was 
207 significantly less abundance in the $\mathrm{CC}$ than in the other treatments.

208 Based on 97\% similarity, only 51 different OTUs were obtained across all samples, indicating the 209 composition of diazotrophic community was very simple. Among them, 15 OTUs had a relative abundance

210 of more than $0.3 \%$ in at least one treatment (Table 4), and the distribution proportion of different OTUs

211 into four treatments was illustrated in Fig. 3. Generally, OTU17 was a dominant member with an average

212 relative abundance ranged from $63.01 \%$ to $87.26 \%$ across all treatments, and its relative abundance was

213 significantly lower in the CC treatment than in the other three treatments. In the rotation system, OTU17

214 was lower in the CSC treatment than in the SCS treatment. A BLAST search at the amino acid level showed

215 that OTU17 had 100\% identity with Bradyrhizobium japonicum (ABO27443). OTU13 was the second most

216 abundant member of the diazotroph and had 99\% identity with Bradyrhizobium sp. (AKN21127). The

217 abundance of OTU13 was at the highest level in CC than in the other treatments. Similarly, other more

218 abundant OTUs were significantly higher in CC than in the other treatments. Particularly, several OTUs

219 classified into the genus Skermanella (OTU5, 10, 26, 30, 31), which showed the highest abundance in the

220 CC treatment (Table 4).

2213.5 Changes of diazotrophic community structures

222 The PCoA plot of all diazotrophic community structures is shown in Fig. 4A. PCoA1 and PCoA2

223 explained $80.87 \%$ and $8.40 \%$ of the variation of the community structures, respectively, indicating that the

224 diazotrophic community structures mainly changed along the PCoA1 axis. All samples were clearly

225 separated into two main groups: one group contained samples of CC, and the other group consisted of 
226 samples from SS, CSC and SCS. Noticeably, although the diazotrophic communities among the treatments

227 of SS, CSC and SCS were grouped closely with each other, the Adonis analysis indicated that the

228 communities were significantly different between SS and CSC $(P=0.028)$, between CSC and SCS $(P=$

229 0.035), but not significant different between SS and SCS $(P=0.055)$ (Table S1). The envfit analysis showed

230 that three soil factors were significantly correlated with change of community structures (Table S2). Of

231 these, $\mathrm{NO}_{3}{ }^{-}-\mathrm{N}$ was positively correlated with the $\mathrm{CC}$ treatment, and $\mathrm{AP}$ was positively correlated with the

232 SS, SCS and CSC treatments (Fig. 4B). In addition, the Mantel test showed that AP $(r=0.26, P=0.038)$

233 was the most important factor in shifting the diazotrophic community structures (Table S3).

\section{4. Discussion}

235 4.1 Changes in soil chemical properties in different cropping systems

236 Previous studies have shown that different cropping systems significantly change the soil chemical

237 properties (Liu et al., 2017). For example, Jagadamma et al. (2008) and Miao et al. (2007) found that soil

$238 \mathrm{pH}, \mathrm{TN}, \mathrm{TC}$ and available nutrient contents were significantly increased after long-term rotation of soybean.

239 However, in this study, we found that soil $\mathrm{pH}$ and $\mathrm{TC}$ had no significant changes among the four treatments.

240 No variation of soil $\mathrm{pH}$ observed in this study might be related to sampling time. The soils were collected

241 near crop maturity in this study, and the soil $\mathrm{pH}$ as influenced by crop exudates might be very weak at this

242 time, similar results was also reported by Meriles et al. (2009), who stated that the soil pH was significantly

243 changed between continuous cropping soybean and soybean-corn rotation system at planting time, while

244 no change was observed at harvest time. The finding of no significant change in soil TC content in this 
245 study is consistent with previous studies (Spargo et al., 2008; Liu et al., 2017), and may be related to the

246 short-term experimental period (only five years) in this study. However, compared with the continuous

247 cropping treatments of SS and CC, TN content in the rotation was significantly higher under the same crop

248 (Table 1). The reasons for this may be related to two aspects: one is the rotation benefit for the growth of

249 soybeans, which can fix more nitrogen from the air and promote the increase of TN content in soils

250 (Adeboye et al., 2006), and the other is that rotations including corn put more $\mathrm{N}$ fertilizer into the soil

251 compared with the SS treatment, which can increase TN content in soil. Similarly, the changes in available

252 nutrients, such as $\mathrm{AP}, \mathrm{NH}_{4}{ }^{+}-\mathrm{N}$ and $\mathrm{NO}_{3}{ }^{-}-\mathrm{N}$, may also be related to different fertilizer regimes between corn

253 cropping and soybean cropping.

254 4.2 Effects of cropping system on the abundance of the nifH gene and diazotroph diversity

255 Previous studies have shown that different cropping systems significantly change the abundance of the

256 nifH gene in agricultural soils (Reardon et al., 2014). In this study, we found that the abundance of the nifH

257 gene was higher in cropping rotation than in continuous cropping when the crop was same (CSC vs CC;

258 SCS $v_{s} \mathrm{SS}$ ), and it was also higher when the growth crop was soybean than when the crop was corn (SS $v s$

259 CC; SCS vs CSC) (Fig. 1A), suggesting that the abundance of the nifH gene is influenced by both cropping

260 system and crop type. In addition, the finding that the nifH gene abundance was negatively correlated with

$261 \mathrm{NO}_{3}^{-}-\mathrm{N}$ in this study (Fig. 1C) is consistent with the result reported by Mirza et al. (2014), who stated that

262 the increase in $\mathrm{NO}_{3}^{-}-\mathrm{N}$ content in soil satisfied the demand of microorganisms for nitrogen, and the

263 abundance of diazotrophs containing the nifH gene was significantly decreased. The finding that the nifH

264 gene abundance is also negatively correlated with C/N (Fig. 1B) is supported by the finding of Wang et al. 
265 (2012), who stated the abundance of nifH gene in both rhizosphere and bulk paddy soil was negatively

266 correlated with $\mathrm{C} / \mathrm{N}$ under different period of organic management. Furthermore, the abundance of the nifH

267 gene is positively correlated with AP (Fig. 1D), suggesting that AP is an important constraint in adjusting

268 the ability of $\mathrm{N}_{2}$ fixation. Similar results were also observed in our previous study, we observed that the

269 nifH gene abundance in a black soil treated with long-term of chemical fertilizers was positively correlated

270 with available $\mathrm{P}$ content but negatively correlated with $\mathrm{NO}_{3}^{-}-\mathrm{N}$ content (Hu et al., 2019).

271 The soil microbial community structures and the diversity index were affected by different cropping

272 systems (Yin et al., 2010). Based on the meta-analysis of the soil microbial diversity index in different

273 cropping systems, Venter et al. (2016) stated that only $15.1 \%$ and $3.4 \%$ of the microbial community richness

274 and diversity index in the rotation system showed an increasing trend, and the changes in the soil microbial

275 diversity index were closely related to the different rotation systems and the years of continuous cropping.

276 In this study, the Shannon index of diazotrophs in the CC treatment was significantly higher than that in

277 the other treatments (Fig. 2), indicating that continuous cropping of corn significantly increased the alpha

278 diversity of the diazotrophic community. This phenomenon may be related to the significant increase in the

279 number of OTU17 in cropping systems including soybean (Table 4), since the increase of a single bacterium

280 can lead to decrease community evenness and Shannon diversity index (Ortiz-Burgos, 2016). Consistent

281 with the results of Navarro et al. (2013), there was no significant difference in the diversity index between

282 the SS and SCS treatments (Fig. 2). In addition, there was no significant difference in the Chao1 and OTU

283 number index among the treatments, suggesting that the crop systems significantly changed the abundance

284 rather than species of the diazotrophic community. Furthermore, the finding that the Shannon index of the 
285 diazotrophic community was significantly negatively correlated with AP content (Table 2) was consistent

286 with the findings of Eisenhauer (2016) and $\mathrm{Hu}$ et al. (2018), which suggested that available P nutrient

287 increased the nifH abundance but relatively simplified the diversity of diazotrophic community. Our

288 findings strongly highlighted that the changes of the diazotrophic community is highly sensitive to $\mathrm{P}$

289 content, and P is an important element for microorganism growth and development (Jean et al., 2013).

2904.3 Effects of cropping systems on diazotrophic community structures

291 The diazotrophs in the black soil ecosystem are dominated by Proteobacteria (Ding et al., 2016).

292 Meanwhile, Silva et al. (2013), based on PCR-DGGE analysis, has shown that Bradyrhizobium is the most

293 abundant genus of diazotrophs in long-term rotation systems. In this study, we found that compared with

294 the CC treatment, the abundance of Rhizobiales was significantly higher in the SS, SCS and CSC treatments

295 (Table 3), which is mainly because most Rhizobiales are symbiotic microbes with the roots of legumes.

296 Inderjit (2005) reported that the quantity and quality of crop secretions from different crops could lead to

297 changes in diazotroph colonization. Consistent with the results of Silva et al. (2013), this study found that

298 Bradyrhizobium japonicum is the dominant species of the diazotrophs in all treatments. We found that the

299 most abundant OTU17, which was classified as B. japonicum, was significantly higher in SS, CSC and SCS

300 than in CC (Table 4), suggesting that a cropping system including soybean is beneficial to the multiplication

301 of this bacterium. Noticeably, although continuous cropping of corn was conducted for 5 five years in this

302 study, the members belonging to the Bradyrhizobium sp. (OTU17 and OTU13) were still in higher

303 abundance than other OTUs in the CC treatment (Table 4). We observed that this result is not surprise since

304 Bradyrhizobium sp. can act as an active endophytic plant growth promoter associated to plants beside of 
305 legume (Videira et al., 2013; Rouws et al., 2014; Menezes Junior et al., 2019). Recently, a study also showed

306 that Bradyrhizobium sp. is the dominant member of the diazotrophic community in the annual rotation of

307 summer corn with winter wheat in southern China (Wang et al., 2017). One of the interesting findings is

308 that the CC treatment led to a higher abundance of OTU13 than in the other three treatments (Table 4). This

309 finding was not reported previously, and the reasons need to be revealed with further studies. Another

310 noteworthy finding was that the OTUs classified into the Skermanella genus had the highest abundance in

311 the CC treatment than the cropping system including soybean (Table 4). However, the relative abundance

312 of Skermanella in CC was only about $10 \%$, which significantly lower that than $50 \%$ of Skermanella

313 observed in 35 years of monoculture of corn in a black soil (Hu et al., 2018). Given the monoculture

314 cropping corn in this study is only five years, we speculate that the relative abundance of Skermanella will

315 be increased with years of continuous corn cropping in the black soils. Although the abundance of

316 Skermanella was increased in the continuous corn cropping system, this event is not benefit for increasing

317 soil $\mathrm{N}$ nutrition, because this genus contains nifH gene but unable to fix $\mathrm{N}_{2}$ (Zhu et al. 2014).

318 The diazotrophic community structure in CC was significantly different from that in the other treatments

319 (Fig. 4A). Meanwhile, the structure of diazotrophs in SCS was markedly different from that in the CSC

320 treatment, suggesting that different crops significantly change the diazotrophic community structure (Kent

321 \& Triplett, 2002; Wardle et al., 2004). Inderjit (2005) reported that the main reason for forming different

322 microbial communities is the allelopathic effects between plants and microorganisms. Soybean and corn

323 secrete different root exudates into the soil, inducing different microbial colonization and a correspondingly

324 change the diazotrophic community structure in soils. Interestingly, there was no significant difference in 
325 the diazotrophic community structures between the SS and SCS treatments, indicating that when the

326 growing crop is soybean, the diazotrophic community structures are not influenced by the cropping system.

327 However, given only five years of continuous soybean cropping involved in this study, whether long-term

328 cropping, such as longer than 10 years of continuous soybean cropping, could change the diazotrophic

329 community structures compared with SCS needs to be addressed in future studies.

330 Both RDA and the Mantel test results showed that AP had the greatest contribution to the changes of the

331 diazotrophic community structures (Fig. 4B; Table S3), indicating that AP is the main driving factor for the

332 variation of diazotrophic communities after changes in cropping systems. Our findings strongly highlight

333 that the changes of the diazotrophic community in this study from aspects of abundance, diversity and

334 community structure are highly sensitive to available P content. The finding of this study is lined with the

335 several previous studies, which indicated that soil phosphorus content is a limiting factor for $\mathrm{N}_{2}$ fixation,

336 and available P induced the largest impacts on soil diazotrophic community (Vitousek et al. 2002; Tang et

337 al. 2017; Hu et al., 2018).

\section{5. Conclusions}

339 In summary, our study demonstrated that several soil properties such as $\mathrm{AP}, \mathrm{C} / \mathrm{N}$ and nitrogen related

340 nutrients were significantly influenced by cropping systems. We found that the abundance of the nifH gene,

341 diversity and structures of diazotrophic communities differed with cropping systems, especially in

342 continuous corn cropping. The soil properties, specially of soil available $\mathrm{P}$ was tested as the critical factors

343 in driving the changes of diazotrophic community, which highlighted that the management of soil 
344 phosphorus nutrient is very important for increasing BNF in black soils. In addition, we observed that the

345 relative abundance of Bradyrhizobium sp. was significantly increased under the cropping systems including

346 soybean. While, the abundance of Skermanella sp. was increased under continuous corn cropping, which

347 suggested that the cropping systems including soybean is favorable for BNF.

348

349

350

351

352

353

354

355

356

357

358

359

360

361

362

\section{References}

Adeboye MKA, Iwuafor ENO, Agbenin JO. 2006. The effects of crop rotation and nitrogen fertilization on soil chemical and microbial properties in a Guinea Savanna Alfisol of Nigeria. Plant and Soil 281:97-107 DOI 10.1007/s11104-005-3828-5.

Ashworth AJ, Allen FL, Debruyn JM, Owens PR, Sams C. 2018. Crop rotations and poultry litter affect dynamic soil chemical properties and soil biota long term. Journal of Environmental Quality 47:13271338 DOI 10.2134/jeq2017.12.0465.

Bai L, Cui J Q, Jie WG, Cai BY. 2015. Analysis of the community compositions of rhizosphere fungi in soybeans continuous cropping fields. Microbiological Research 180:49-56 DOI 10.1016/j.micres.2015.07.007.

Bennett AJ, Bending GD, Chandler D, Hilton S, Mills P. 2012. Meeting the demand for crop production: the challenge of yield decline in crops grown in short rotations. Biological Reviews 87:52-71 DOI 10.1111/j.1469-185X.2011.00184.x.

Calderoli PA, Collavino MM, Kraemer FB, Morras HJM, Aguilar OM. 2017. Analysis of nifH-RNA reveals phylotypes related to Geobacter and Cyanobacteria as important functional components of the 
$\mathrm{N}_{2}$-fixing community depending on depth and agricultural use of soil. MicrobiologyOpen 6:e00502 DOI 10.1002/mbo3.502.

Caporaso JG, Kuczynski J, Stombaugh J. 2010. QIIME allows analysis of high-throughput community sequencing data. Nature Methods 7:335-336 DOI 10.1038/nmeth.f.303.

Clarke KR. 1993. Nonparametric multivariate analyses of changes in community structure. Austral Ecology 18:117-143 DOI 10.1111/j.1442-9993.1993.tb00438.x.

Coelho MRR, Marriel IE, Jenkins SN, Lanyon CV, Seldin L, O'Donnell AG. 2009. Molecular detection and quantification of nifH gene sequences in the rhizosphere of sorghum (Sorghum bicolor) sown with two levels of nitrogen fertilizer. Applied Soil Ecology 42:48-53 DOI 10.1016/j.apsoil.2009.01.010.

Collavino MM, Tripp HJ, Frank IE, Vidoz ML, Calderoll PA, Donato M, Zehr JP, Aguilar OM. 2014. nifH pyrosequencing reveals the potential for location-specific soil chemistry to influence $\mathrm{N}_{2}$ fixing community dynamics. Environmental Microbiology 16:3211-3223 DOI 10.1111/14622920.12423.

Davies-Barnard T, Friedlingstein P (2020). The global distribution of biological nitrogen fixation in terrestrial natural ecosystems. Global Biogeochemical Cycles 34 (3): e2019GB006387. DOI: 10.1029/2019GB006387

Dias T, Dukes A, Antunes PM. 2015. Accounting for soil biotic effects on soil health and crop productivity in the design of crop rotations. Journal of the Science of Food and Agriculture 95:447-454 DOI $10.1002 /$ jsfa. 6565 .

Ding JL, Jiang X, Ma MC, Zhou BK, Guan DW, Zhao BS, Zhou J, Cao FM, Li L, Li J. 2016. Effect of 35 years inorganic fertilizer and manure amendment on structure of bacterial and archaeal 
communities in black soil of northeast China. Applied Soil Ecology 105:187-195 DOI

10.1016/j.apsoil.2016.04.010.

386

387

388

389

390

391

392

393

Edgar RC, Haas BJ, Clemente JC, Quince C, Knight R. 2011. UCHIME improves sensitivity and speed of chimera detection. Bioinformatics 27:2194 DOI 10.1093/bioinformatics/btr381.

Eisenhauer N. 2016. Plant diversity effects on soil microorganisms: Spatial and temporal heterogeneity of plant inputs increase soil biodiversity. Pedobiologia 59:175-177 DOI 10.1016/j.pedobi.2016.04.004.

Fan KK, Weisenhorn P, Gilbert JA, Shi Y, Bai Y, Chu HY. 2018. Soil pH correlates with the cooccurrence and assemblage process of diazotrophic communities in rhizosphere and bulk soils of wheat fields. Soil Biology and Biochemistry 121:185-192 DOI 10.1016/j.soilbio.2018.03.017.

Hu XJ, Liu JJ, Zhu P, Wei D, Jin J, Liu XB, Wang GH. 2018. Long-term manure addition reduces diversity and changes community structure of diazotrophs in a neutral black soil of northeast China. Journal of Soils and Sediments 18:2053-2062 DOI 10.1007/s11368-018-1975-6.

Hu XJ, Liu JJ, Wei D, Zhou BK, Chen XL, Jin J, Liu XB, Wang GH. 2019. Long-term application of nitrogen, not phosphate or potassium, significantly alters the diazotrophic community compositions and structures in a Mollisol in northeast China. Research in Microbiology 170:147-155 DOI 10.1016/j.resmic.2019.02.002.

Huang LF, Song LX, Xia XJ, Mao WH, Shi K, Zhou YH, Yu JQ. 2013. Plant-soil feedbacks and soil sickness: from mechanisms to application in agriculture. Journal of Chemical Ecology 39:232-242 DOI 10.1007/s10886-013-0244-9.

Inderjit. 2005. Soil microorganisms: An important determinant of allelopathic activity. Plant and Soil 274:227-236 DOI 10.1007/s11104-004-0159-x. 
405 Jagadamma S, Lal R, Hoeft RG, Naffiger ED, Adee EA. 2008. Nitrogen fertilization and cropping

406 system impacts on soil properties and their relationship to crop yield in the central corn belt, USA.

$407 \quad$ Soil and Tillage Research 98:120-129 DOI 10.1016/j.still.2007.10.008.

408 Jean ME, Phalyvong K, Forestdrolet J, Bellenger JP. 2013. Molybdenum and phosphorus limitation of

409 asymbiotic nitrogen fixation in forests of Eastern Canada: Influence of vegetative cover and seasonal

410 variability. Soil Biology and Biochemistry 67:140-146 DOI 10.1016/j.soilbio.2013.08.018.

411 Jha MN, Prasad AN, Misra SK. 2004. Influence of source of organics and soil organic matter content on

412 cyanobacterial nitrogen fixation and distributional pattern under different water regimes. World

413 Journal of Microbiology and Biotechnology 20:673-677 DOI 10.1007/s11274-004-2157-9.

414 Jirak-Peterson JC, Esker PD. 2011. Tillage, crop rotation, and hybrid effects on residue and corn

415 anthracnose occurrence in Wisconsin. Plant Disease 95:601-610 DOI 10.1094/PDIS-11-10-0837.

416 Krzywinski M, Schein J, Birol I, Connors J, Gascoyne R, Horsman D. 2009. Circos: an

417 information aesthetic for comparative genomics. Genome Research 19:1639-1645 DOI

$418 \quad$ 10.1101/gr.092759.109.

419 Kent AD, Triplett EW. 2002. Microbial communities and their interactions in soil and rhizosphere ecosystems. Annual Review of Microbiology 56:211-236 DOI 10.1146/annurev.micro.56.012302.161120.

Liang AZ, Zhai ZL, Mclaughlin NB, Yang XM, Zhang XP, Chen XW, Sun BJ. 2017. Lodging in corn varies with tillage and crop rotation: A case study after Typhoon Bolaven pummeling over the black 
424

425

426

427

428

429

430

431

432

433

434

435

436

437

438

439

440

441

442

443

444

soil zone in northeast China. Pakistan Journal of Agricultural Sciences 54:539-545 DOI

10.21162/PAKJAS/17.4156.

Liu JJ, Yu ZH, Yao Q, Hu XJ, Zhang W, Mi G, Chen XL, Wang GH. 2017. Distinct soil bacterial communities in response to the cropping system in a Mollisol of northeast China. Applied Soil Ecology 119:407-416 DOI 10.1016/j.apsoil.2017.07.013.

Liu XB, Jin J, Wang GH, Herbert SJ. 2008. Soybean yield physiology and development of high-yielding practices in Northeast China. Field Crops Research 105:157-171 DOI 10.1016/j.fcr.2007.09.003.

Lu RK. 2000. Analytical methods for soil and agro-chemistry. Beijing: China Agricultural Science and Technology Press (In Chinese).

Menezes Júnior IDA, Matos GFD, Freitas KMD, Jesus EDC, Rouws LFM. 2019. Occurrence of diverse Bradyrhizobium spp. in roots and rhizospheres of two commercial Brazilian sugarcane cultivars. Brazilian Journal of Microbiology 50:759-767 DOI 10.1007/s42770-019-00090-6.

Meriles JM, Gil SV, Conforto C, Figoni G, Lovera E, March GJ, Guzman CA. 2009. Soil microbial communities under different soybean cropping systems: characterization of microbial population dynamics, soil microbial activity, microbial biomass, and fatty acid profiles. Soil and Tillage Research 103:271-281 DOI 10.1016/j.still.2008.10.008.

Miao SJ, Qiao YF, Hang XZ. 2007. Review of researches on obstacles of continuous cropping of soybean. Chinese Journal of Eco-Agriculture 15:203-206 (In Chinese).

Mirza BS, Potisap C, Nüsslein K, Bohannan BJM, Rodrigues JLM. 2014. Response of free-living nitrogen-fixing microorganisms to land use change in the Amazon rainforest. Applied and Environmental Microbiology 80:281-288 DOI 10.1128/AEM.02362-13. 
445

446

447

448

449

450

451

452

453

Moisander PH, Cheshire LA, Braddy J, Calandrino ES, Hoffman M, Piehier MF, Paerl HW. 2012. Facultative diazotrophy increases Cylindrospermopsis raciborskii competitiveness under fluctuating nitrogen availability. FEMS Microbiology Ecology 79:800-811 DOI $\quad$ 10.1111/j.15746941.2011.01264.x.

Navarro NYE, Gómez AS, Montoya CN, Rojas VA, Suarez AMC, Valenzuela EC, Jimenez BN, Verhulst N, Govaerts B, Dendooven L. 2013. Relative impacts of tillage, residue management and crop-rotation on soil bacterial communities in a semi-arid agroecosystem. Soil Biology and Biochemistry 65:86-95 DOI 10.1016/j.soilbio.2013.05.009.

R Development Core Team. 2006. R, a language and environment for statistical computing. R 21 . Foundation for Statistical Computing, Vienna, Austria.

Reardon CL, Gollany HT, Wuest SB. 2014. Diazotroph community structure and abundance in wheatfallow and wheat-pea crop rotations. Soil Biology and Biochemistry 69:406-412 DOI 10.1016/j.soilbio.2013.10.038.

Rösch C, Mergel A, Bothe H. 2002. Biodiversity of denitrifying and dinitrogen-fixing bacteria in an acid forest soil. Applied and Environmental Microbiology 68:3818-3829 DOI 10.1128/AEM.68.8.38183829.2002 .

Rouws LFM, Leite J, De Matos GF, Zilli JE, Coelho MRR, Xavier GR, Fischer D, Hartmann A, Reis VM, Baldani JI. 2014. Endophytic Bradyrhizobium spp. isolates from sugarcane obtained through different culture strategies. Environmental Microbiology Reports 6(4):354-363 DOI 10.1111/17582229.12122 . 
465 Ortiz-Burgos S. 2016. Shannon-Weaver Diversity Index. Springer Netherlands DOI 10.1007/978-94-017-

466 8801-4_233.

467 Silva MCPE, Schloterhai B, Schloter M, Elsas JD, Salles JF. 2013. Temporal dynamics of abundance

468 and composition of nitrogen-fixing communities across agricultural soils. PLoS One 8:e74500 DOI:

$469 \quad$ 10.1371/journal.pone.0074500.

470

471

472

473

474

475

476

477

478

479

480

481

482

483

Spargo JT, Alley MM, Follett RF, Wallace JV. 2008. Soil nitrogen conservation with continuous no-till management. Nutrient Cycling in Agroecosystems 82:283-297 DOI 10.1007/s10705-008-9190-2.

Tang YF, Zhang MM, Chen AL, Zhang WZ, Wei WX, Sheng R. 2017. Impact of fertilization regimes on diazotrophy community compositions and $\mathrm{N}_{2}$-fixation activity in paddy soil. Agriculture Ecosystems \& Environment 247:1-8 DOI 10.1016/j.agee.2017.06.009.

Torres FZV, Souza DA, Lira ED, Faria M, Sujii E, Lopes RB. 2018. Occurrence of the anamorphic stage of Ophiocordyceps myrmicarum on a non-Formicidae insect in integrated crop-livestock farming systems. Fungal Ecology 34:83-90 DOI 10.1016/j.funeco.2018.05.009.

Venter ZS, Jacobs K, Hawkins HJ. 2016. The impact of crop rotation on soil microbial diversity: A metaanalysis. Pedobiologia 59:215-223 DOI 10.1016/j.pedobi.2016.04.001.

Videira S S, Cássia MDCPE, Souza Galisa PD, Dias ACF, Nissinen R, Divan VLB, Van Elsas JD, Baldani JI, Salles JF. 2013. Culture-independent molecular approaches reveal a mostly unknown high diversity of active nitrogen-fixing bacteria associated with Pennisetum purpureum —a bioenergy crop. Plant \& Soil 373(1-2):737-754 DOI 10.1007/s11104-013-1828-4. 
484 Vitousek PM, Cassman K, Cleveland C, Crews T, Field CB, Grimm NB, Howarth RW, Marino R,

485 Martinelli L, Rastetter EB, Sprent JI. 2002. Towards an ecological understanding of biological

486 nitrogen fixation. Biogeochemistry 57:1-45

487 Wang C, Zheng M, Song WF, Wen SL, Wang BR, Zhu CQ, Shen RF. 2017. Impact of 25 years of

488 inorganic fertilization on diazotrophic abundance and community structure in an acidic soil in southern China. Soil Biology and Biochemistry 113:240-249 DOI 10.1016/j.soilbio.2017.06.019.

Wang S, Pablo GP, Ye J, Huang DF. 2012. Abundance and diversity of nitrogen-fixing bacteria in

491

rhizosphere and bulk paddy soil under different duration of organic management. World Journal of Microbiology and Biotechnology 28:493-503 DOI 10.1007/s11274-011-0840-1.

Wang YS, Li CN, Kou YP, Wang JJ, Tu B, Li H, Li XZ, Wang CT, Yao MJ. 2017. Soil pH is a major driver of soil diazotrophic community assembly in qinghai-tibet alpine meadows. Soil Biology and Biochemistry 115:547-555 DOI 10.1016/j.soilbio.2017.09.024.

Wardle DA, Bardgett RD, Klironomos JN, Setala H, Putten WH, Wall DH. 2004. Ecological linkages between aboveground and belowground biota. Science 304:1629-1633 DOI 10.1126/science.1094875.

Xiao CH, Tang H, Pu LJ, Sun DM, Ma JZ, Yu M, Duan RS. 2010. Diversity of nitrogenase (nifH) genes pool in soybean field soil after continuous and rotational cropping. Journal of Basic Microbiology 50: 373-379 DOI 10.1002/jobm.200900317.

Xiong W, Zhao QY, Zhao J, Xun WB, Li R, Zhang RF, Wu HS, Shen QR. 2015. Different continuous cropping spans significantly affect microbial community membership and structure in a vanilla-grown 
soil as revealed by deep pyrosequencing. Microbial Ecology 70:209-218 DOI 10.1007/s00248-0140516-0.

Xu YL, Li CJ, Li ZL. 2004. Effects of corn rotation and continuous cropping system on weed population. Chinese Journal of Ecology 23:37-40 (In Chinese).

Yin CT, Jones KL, Peterson DE, Garrett KA, Hulbert SH, Paulitz TC. 2010. Members of soil bacterial communities sensitive to tillage and crop rotation. Soil Biology and Biochemistry 42:2111-2118 DOI 10.1016/j.soilbio.2010.08.006.

Zhu SY, Wang YZ, Xu XM, Liu TM, Wu DQ, Zheng X, Tang SW, Dai QZ. 2018. Potential use of high-throughput sequencing of soil microbial communities for estimating the adverse effects of continuous cropping on ramie (Boehmeria nivea L. Gaud). PLoS One 13:e0197095 DOI 10.1371/journal.pone.0197095.

515 Zhu W, Huang J, Li M, Li X, Wang G. 2014. Genomic analysis of Skermanella stibiiresistens type strain SB22T . Standards in Geonomic Sciences 9:1211-1220 DOI:10.4056/sigs.5751047. 
Figure 1

Effect of different cropping systems on diazotrophic nifH gene abundance $(A)$ and the bivariate correlation between the abundance of the nifH gene and soil $\mathrm{C} / \mathrm{N}(\mathrm{B}), \mathrm{NO}_{3}^{-}-\mathrm{N}$ (C) and AP content (D) in black soil

CC and SS represent the treatments of continuous cropping corn and soybean, respectively; CSC and SCS represent the treatments of soybean-corn rotation for growing corn and soybean, respectively. Error bars show the standard deviation of abundance, and the bars marked with different letters show the significant difference at $P<0.05$.
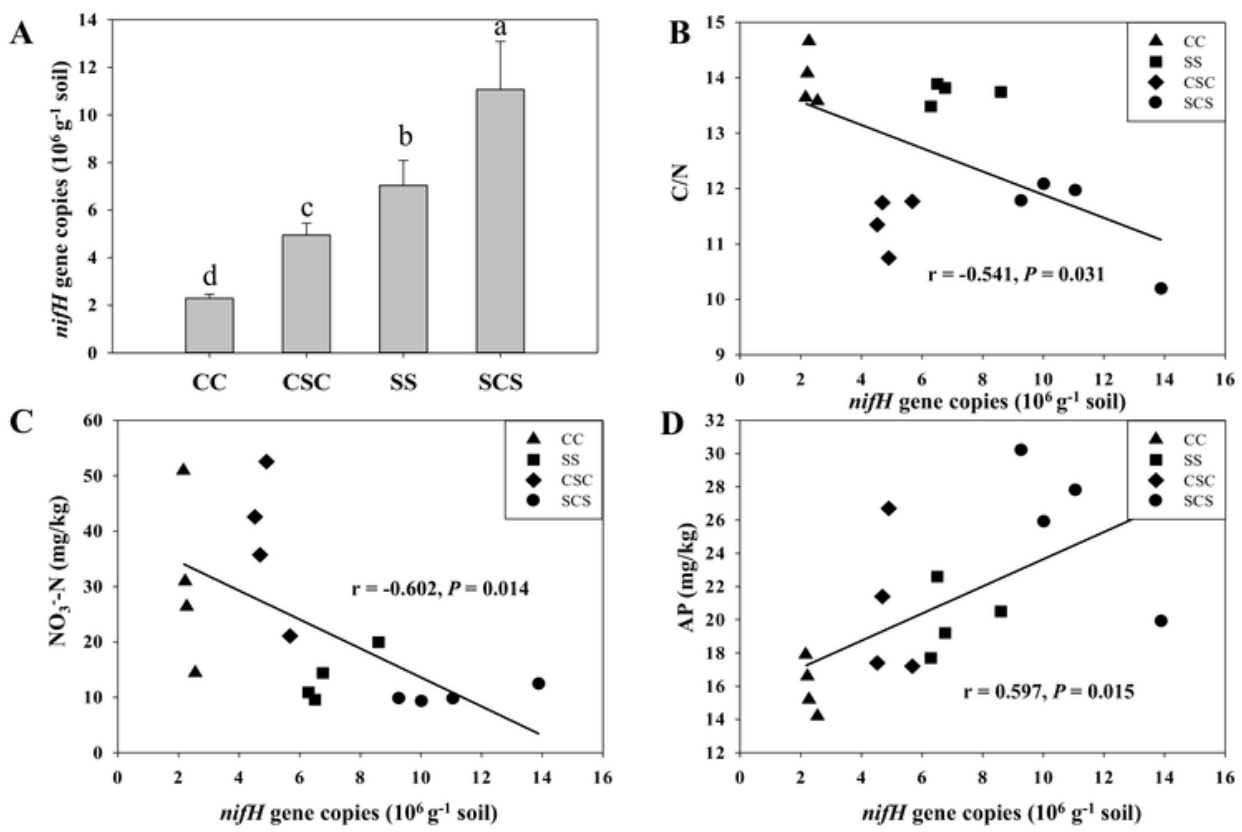
Figure 2

Effect of different cropping systems on the Shannon indice (A), Simpson indice (B), OTU number (C) and Chaol indice (D) of alpha diversity of diazotrophic communities calculated based on a randomly selected subset of 6545 sequences per sample.

The abbreviations of CC, SS, CSC and SCS are described in Figure 1. The bars marked with different letters show the significant difference at $P<0.05$.
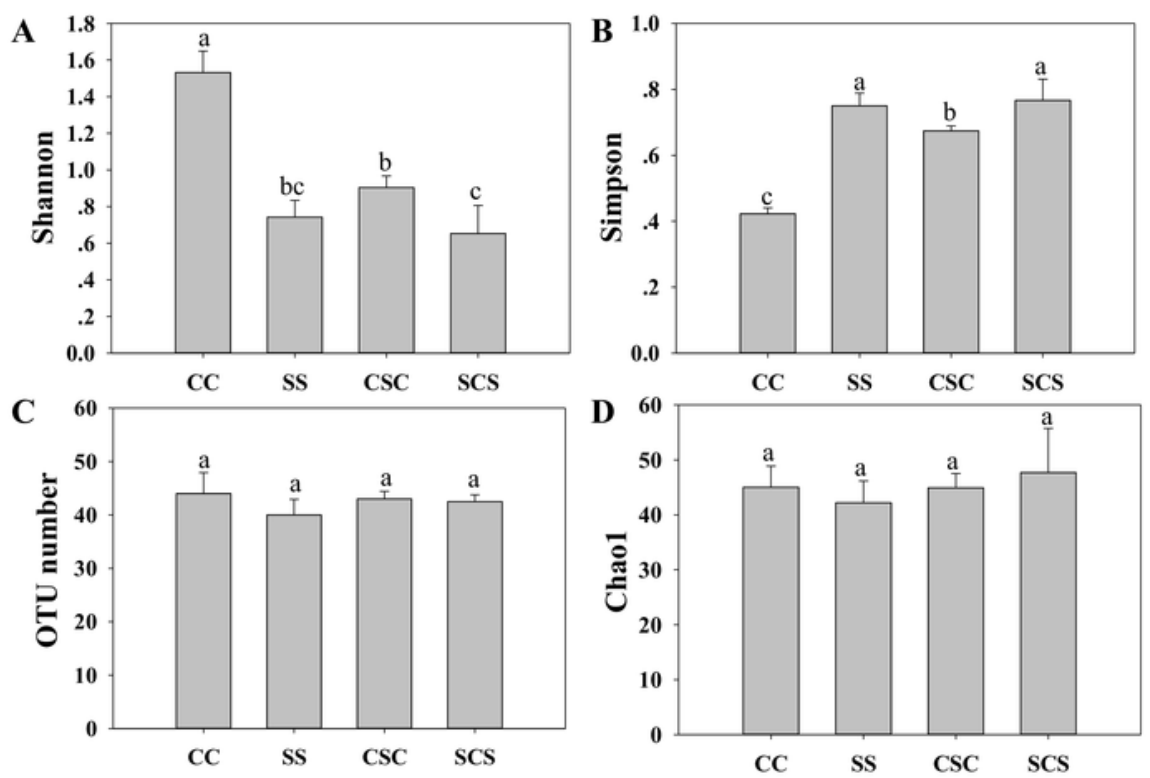
Figure 3

Circular representation of microbial communities in CC, SS, CSS, SCS at OTU level. The inner circular diagram show the relative abundance of different OTUs in different treatments. OTUs with relative abundance lower than $0.3 \%$ in all samples were not shown

The abbreviations of CC, SS, CSC and SCS are described in Figure 1. 


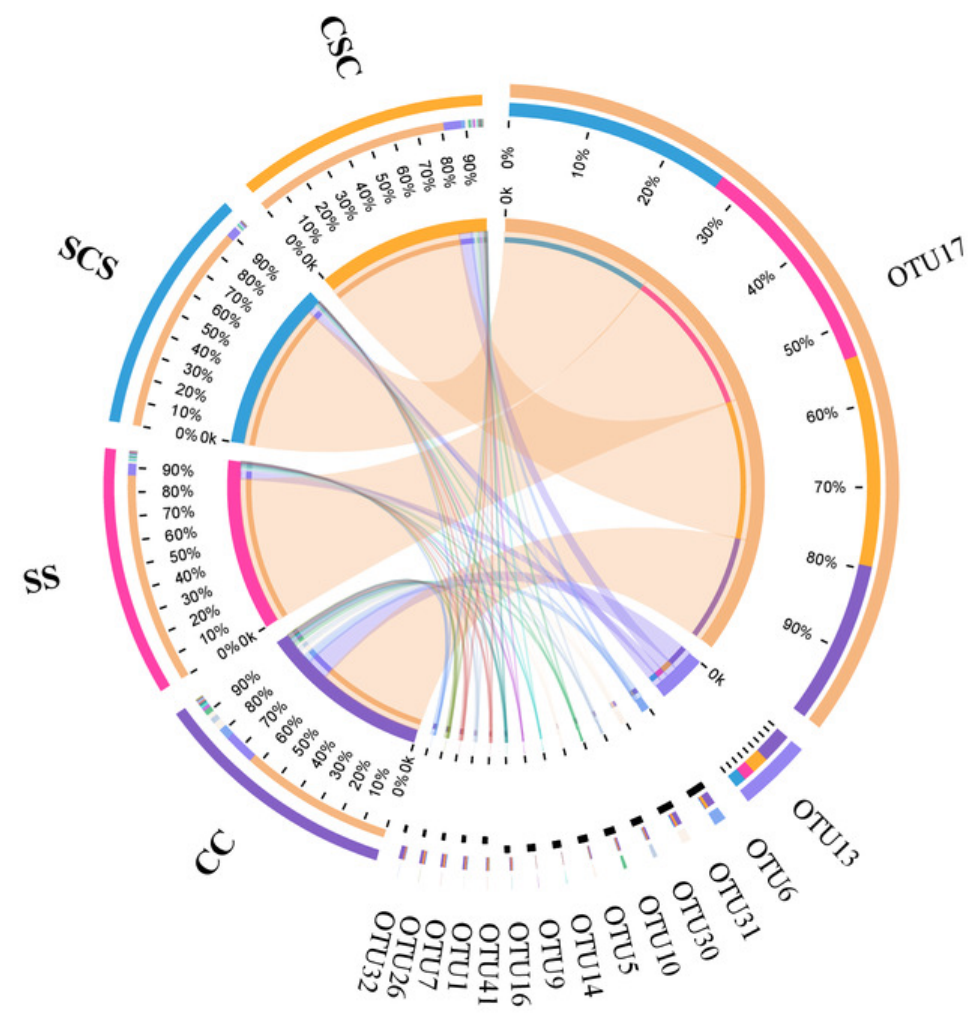


Figure 4

Principal coordinate analysis (A) and redundancy analysis (B) of soil diazotrophic communities in different cropped systems.

The abbreviations of CC, SS, CSC and SCS are described in Figure 1.
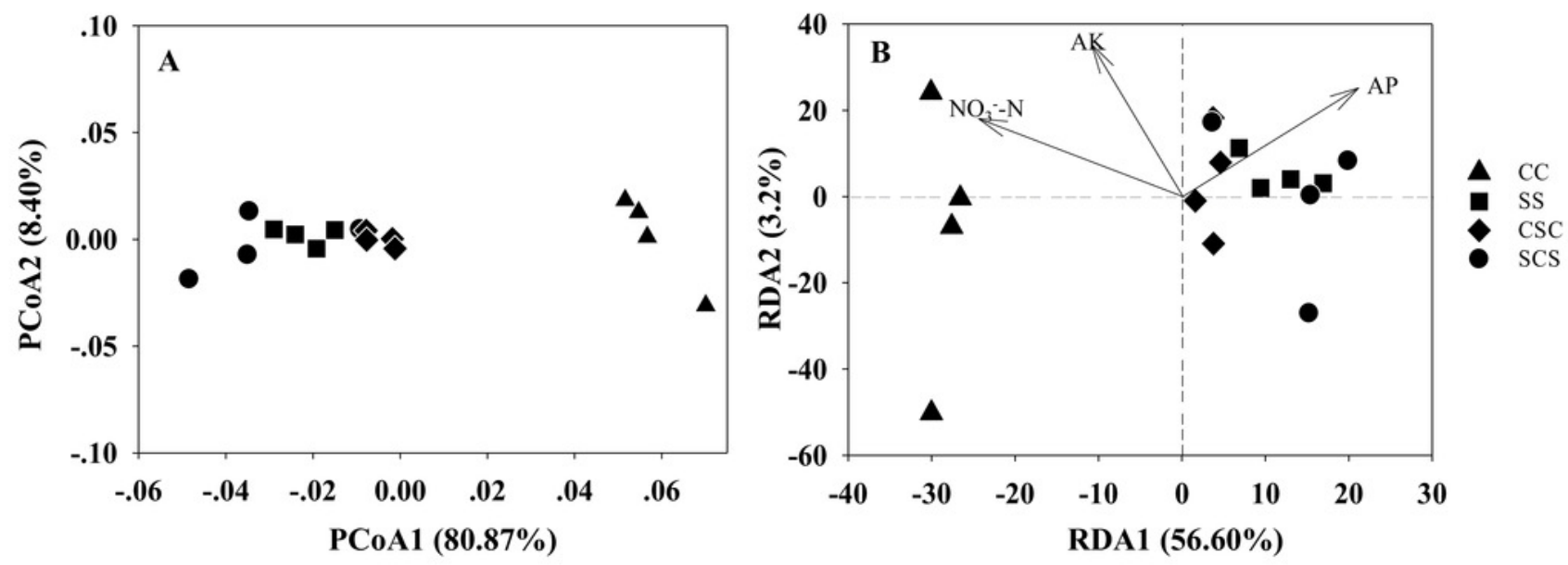
Table $\mathbf{1}$ (on next page)

Effects of different cropping systems on soil chemical properties. 
1 Table 1 Effects of different cropping systems on soil chemical properties

\begin{tabular}{|c|c|c|c|c|c|c|c|c|c|c|}
\hline Treatment & $\mathrm{pH}$ & $\mathrm{TN}\left(\mathrm{g} \mathrm{kg}^{-1}\right)^{\ddagger}$ & $\mathrm{TC}\left(\mathrm{g} \mathrm{kg}^{-1}\right)^{\ddagger}$ & $\mathrm{C} / \mathrm{N}$ & $\mathrm{TP}\left(\mathrm{g} \mathrm{kg}^{-1}\right)^{\ddagger}$ & $\mathrm{TK}\left(\mathrm{g} \mathrm{kg}^{-1}\right)^{\ddagger}$ & $\mathrm{NH}_{4}{ }^{+}-\mathrm{N}\left(\mathrm{mg} \mathrm{kg}^{-1}\right)$ & $\mathrm{NO}_{3}{ }^{-}-\mathrm{N}\left(\mathrm{mg} \mathrm{kg}^{-1}\right)$ & $\mathrm{AP}\left(\mathrm{mg} \mathrm{kg}^{-1}\right)^{\ddagger}$ & $\mathrm{AK}\left(\mathrm{mg} \mathrm{kg}^{-1}\right)^{\ddagger}$ \\
\hline $\mathrm{CC}^{\dagger}$ & $6.39 \pm 0.12 \mathrm{a}^{\S}$ & $1.57 \pm 0.16 \mathrm{bc}$ & $21.94 \pm 2.62 \mathrm{a}$ & $13.99 \pm 0.50 \mathrm{a}$ & $0.56 \pm 0.029 \mathrm{a}$ & $15.64 \pm 0.25 \mathrm{a}$ & $18.83 \pm 1.37 \mathrm{~b}$ & $30.66 \pm 5.21 \mathrm{~b}$ & $15.98 \pm 1.62 \mathrm{c}$ & $231.05 \pm 14.11 \mathrm{a}$ \\
\hline $\mathrm{SS}^{\dagger}$ & $6.36 \pm 0.01 \mathrm{a}$ & $1.52 \pm 0.12 \mathrm{c}$ & $20.90 \pm 1.88 \mathrm{a}$ & $13.73 \pm 0.17 \mathrm{a}$ & $0.56 \pm 0.035 \mathrm{a}$ & $15.79 \pm 0.20 \mathrm{a}$ & $17.74 \pm 1.68 \mathrm{~b}$ & $13.69 \pm 3.64 \mathrm{c}$ & $20.00 \pm 2.08 \mathrm{~b}$ & $219.55 \pm 11.29 a$ \\
\hline $\mathrm{CSC}^{\dagger}$ & $6.36 \pm 0.16 \mathrm{a}$ & $1.84 \pm 0.15 \mathrm{a}$ & $20.97 \pm 2.40 \mathrm{a}$ & $11.40 \pm 0.48 b$ & $0.47 \pm 0.023 b$ & $15.97 \pm 0.16 \mathrm{a}$ & $24.22 \pm 1.35 \mathrm{a}$ & $37.98 \pm 3.23 \mathrm{a}$ & $20.68 \pm 2.46 \mathrm{~b}$ & $223.57 \pm 9.84 \mathrm{a}$ \\
\hline $\mathrm{SCS}^{\dagger}$ & $6.34 \pm 0.09 \mathrm{a}$ & $1.78 \pm 0.13 \mathrm{ab}$ & $20.47 \pm 2.67 \mathrm{a}$ & $11.50 \pm 0.86 b$ & $0.56 \pm 0.035 \mathrm{a}$ & $15.68 \pm 0.40 \mathrm{a}$ & $18.13 \pm 1.12 b$ & $10.28 \pm 1.42 \mathrm{c}$ & $25.96 \pm 2.40 \mathrm{a}$ & $234.96 \pm 12.21 \mathrm{a}$ \\
\hline
\end{tabular}

$2 \uparrow \mathrm{CC}, \mathrm{SS}, \mathrm{CSC}$ and SCS represent continuous corn cropping, continuous soybean cropping, soybean-corn rotation for growing crop was corn and

3 soybean-corn rotation for growing crop was soybean, respectively.

$4 \ddagger \mathrm{TN}, \mathrm{TC}, \mathrm{TP}, \mathrm{TK}, \mathrm{AP}$ and AK represent soil total nitrogen, total carbon, total phosphorus, total potassium, available phosphorus and available potassium,

5 respectively.

$6 \S$ Different letters within the same column indicate significant difference between treatments tested by one-way ANOVA $(P<0.05)$. Values are the means $7 \pm \operatorname{SE}(n=4)$. 


\section{Table 2 (on next page)}

The bivariate correlation between the alpha diversity of diazotrophic communities and soil factors. 
1 Table 2 The bivariate correlation between alpha diversity of diazotrophic communities and soil factors.

\begin{tabular}{|c|c|c|c|c|c|c|c|c|c|c|}
\hline Diversity index ${ }^{\dagger}$ & $\mathrm{pH}$ & $\mathrm{TN}$ & $\mathrm{TC}$ & $\mathrm{C} / \mathrm{N}$ & $\mathrm{NH}_{4}^{+}-\mathrm{N}$ & $\mathrm{NO}_{3}^{-}-\mathrm{N}$ & $\mathrm{AP}^{\ddagger}$ & $\mathrm{AK}^{\prime}$ & $\mathrm{TP}$ & $\mathrm{TK}^{\ddagger}$ \\
\hline OTU number & -0.163 & -0.095 & -0.245 & -0.121 & 0.146 & -0.020 & -0.297 & -0.063 & -0.009 & -0.048 \\
\hline Shannon & 0.095 & -0.329 & 0.167 & $0.517 * \S$ & 0.006 & 0.356 & $-0.664 * * \S$ & 0.037 & 0.107 & -0.146 \\
\hline Simpson & -0.099 & 0.292 & -0.171 & $-0.478 *$ & -0.032 & -0.421 & $0.627 * *$ & -0.096 & -0.111 & 0.161 \\
\hline Chaol & -0.088 & 0.253 & 0.072 & -0.174 & -0.170 & -0.267 & -0.013 & 0.065 & 0.187 & 0.117 \\
\hline
\end{tabular}

$2 \uparrow$ All indices are calculated based on the minimum number of 6545 sequences per sample.

$3 \ddagger \mathrm{TN}, \mathrm{TC}, \mathrm{TP}, \mathrm{TK}, \mathrm{AP}$ and AK represent soil total nitrogen, total carbon, total phosphorus, total potassium, available phosphorus and available potassium,

4 respectively.

$5 \&$ and ** represent significant correlation at $P<0.05$ and $P<0.01$ level, respectively. 


\section{Table 3(on next page)}

Relative abundances of the dominant diazotrophic bacteria at different taxonomic levels in different cropping systems. 
1 Table 3 Relative abundance (\%) of the dominant diazotrophic bacteria at different taxonomic 2 levels in different cropping systems.

\begin{tabular}{|c|c|c|c|c|}
\hline \multirow{2}{*}{ Taxa } & \multicolumn{4}{|l|}{ Treatments } \\
\hline & $\mathrm{CC}^{\dagger}$ & $\mathrm{SS}^{\dagger}$ & $\mathrm{CSC}^{\dagger}$ & $\mathrm{SCS}^{\dagger}$ \\
\hline \multicolumn{5}{|l|}{ Phylum } \\
\hline Cyanobacteria & $0.08 \pm 0.01 \mathrm{a}^{\ddagger}$ & $0.09 \pm 0.03 \mathrm{a}$ & $0.00 \pm 0.01 \mathrm{~b}$ & $0.03 \pm 0.02 \mathrm{a}$ \\
\hline Proteobacteria & $99.92 \pm 0.13 b$ & $99.91 \pm 0.13 b$ & $100.00 \pm 0.01 \mathrm{a}$ & $99.97 \pm 0.05 b$ \\
\hline \multicolumn{5}{|l|}{ Class } \\
\hline Alphaproteobacteria & $94.35 \pm 1.87 \mathrm{a}$ & $95.33 \pm 0.55 \mathrm{a}$ & $94.93 \pm 0.83 \mathrm{a}$ & $96.13 \pm 1.45 \mathrm{a}$ \\
\hline Betaproteobacteria & $1.37 \pm 0.37 \mathrm{a}$ & $0.97 \pm 0.28 \mathrm{ab}$ & $1.30 \pm 0.16 \mathrm{a}$ & $0.65 \pm 0.30 \mathrm{~b}$ \\
\hline Deltaproteobacteria & $1.56 \pm 0.93 \mathrm{a}$ & $1.20 \pm 0.48 \mathrm{a}$ & $1.71 \pm 0.84 \mathrm{a}$ & $0.85 \pm 0.20 \mathrm{a}$ \\
\hline \multicolumn{5}{|l|}{ Order } \\
\hline Burkholderiales & $1.47 \pm 0.37 \mathrm{a}$ & $0.98 \pm 0.28 \mathrm{bc}$ & $1.30 \pm 0.13 \mathrm{ab}$ & $0.55 \pm 0.32 \mathrm{c}$ \\
\hline Desulfuromonadales & $1.48 \pm 0.92 \mathrm{a}$ & $1.15 \pm 0.49 \mathrm{a}$ & $1.65 \pm 0.88 \mathrm{a}$ & $0.80 \pm 0.18 \mathrm{a}$ \\
\hline Myxococcales & $0.16 \pm 0.16 \mathrm{a}$ & $0.05 \pm 0.01 \mathrm{a}$ & $0.06 \pm 0.05 \mathrm{a}$ & $0.05 \pm 0.03 \mathrm{a}$ \\
\hline Nostocales & $0.01 \pm 0.01 \mathrm{a}$ & $0.02 \pm 0.01 \mathrm{a}$ & $0.01 \pm 0.01 \mathrm{a}$ & $0.03 \pm 0.02 \mathrm{a}$ \\
\hline Rhizobiales & $81.97 \pm 1.45 b$ & $92.14 \pm 1.26 \mathrm{a}$ & $90.78 \pm 1.90 \mathrm{a}$ & $92.47 \pm 2.58 \mathrm{a}$ \\
\hline Rhodospirillales & $10.09 \pm 2.63 \mathrm{a}$ & $2.75 \pm 0.57 \mathrm{~b}$ & $4.09 \pm 1.15 b$ & $2.09 \pm 1.37 \mathrm{~b}$ \\
\hline \multicolumn{5}{|l|}{ Family } \\
\hline Alcaligenaceae & $1.47 \pm 0.37 \mathrm{a}$ & $0.98 \pm 0.28 \mathrm{bc}$ & $1.31 \pm 0.13 \mathrm{ab}$ & $0.55 \pm 0.32 \mathrm{c}$ \\
\hline Bradyrhizobiaceae & $63.20 \pm 1.19 b$ & $86.43 \pm 2.27 \mathrm{a}$ & $81.71 \pm 0.89 \mathrm{a}$ & $87.25 \pm 3.92 \mathrm{a}$ \\
\hline Geobacteraceae & $1.48 \pm 0.92 \mathrm{a}$ & $1.22 \pm 0.57 \mathrm{a}$ & $1.65 \pm 0.88 \mathrm{a}$ & $0.80 \pm 0.18 \mathrm{a}$ \\
\hline Cystobacterineae & $0.16 \pm 0.16 \mathrm{a}$ & $0.05 \pm 0.01 \mathrm{a}$ & $0.06 \pm 0.05 \mathrm{a}$ & $0.05 \pm 0.03 \mathrm{a}$ \\
\hline Nostocaceae & $0.08 \pm 0.01 \mathrm{a}$ & $0.09 \pm 0.03 \mathrm{a}$ & $0.00 \pm 0.01 \mathrm{~b}$ & $0.03 \pm 0.02 \mathrm{a}$ \\
\hline Rhodospirillaceae & $10.09 \pm 2.63 \mathrm{a}$ & $2.75 \pm 0.57 \mathrm{~b}$ & $4.09 \pm 1.15 b$ & $2.09 \pm 1.37 \mathrm{~b}$ \\
\hline
\end{tabular}

$3+$ Abbreviation for treatments are described in Table 1.

$4 \quad$ Different letters within the same row indicate significant difference between treatments tested by one-way 5 ANOVA $(P<0.05)$. Values are the means $\pm \operatorname{SE}(\mathrm{n}=4)$. 


\section{Table 4 (on next page)}

Identification of the abundant OTUs (relative abundance $>0.3 \%$ at least in one treatment) at the amino acid sequence level by BLASTp on the NCBI website and changes in their relative abundances (\%) as influenced by different cropping treatments. 
1 Table 4 Identification of the abundant OTUs (relative abundance $>0.3 \%$ at least in one treatment) at amino acid sequence level by

2 BLASTp on the NCBI website and changes of their relative abundance (\%) as influenced by different cropping treatments.

\begin{tabular}{|c|c|c|c|c|c|c|c|}
\hline OTU ID & Closest relatives & Access number & Identity & $\mathrm{CC}^{\dagger}$ & $\mathrm{SS}^{\dagger}$ & $\mathrm{CSC}^{\dagger}$ & $\mathrm{SCS}^{\dagger}$ \\
\hline OTU1 & Geobacter pickeringii & WP039743917 & $99 \%$ & $0.56 \pm 0.46 \mathrm{a}^{\ddagger}$ & $0.19 \pm 0.03 \mathrm{a}$ & $0.28 \pm 0.14 \mathrm{a}$ & $0.15 \pm 0.11 \mathrm{a}$ \\
\hline OTU5 & Skermanella aerolata & WP044431865 & $99 \%$ & $2.06 \pm 0.75 \mathrm{a}$ & $0.43 \pm 0.06 b$ & $0.77 \pm 0.11 \mathrm{~b}$ & $0.41 \pm 0.32 b$ \\
\hline OTU6 & Burkholderiales bacterium JOSHI_001 & WP009549047 & $100 \%$ & $4.74 \pm 3.06 \mathrm{a}$ & $0.44 \pm 0.06 \mathrm{~b}$ & $1.75 \pm 0.97 \mathrm{~b}$ & $0.40 \pm 0.16 \mathrm{~b}$ \\
\hline OTU7 & Azospirillum & WP085088510 & $97 \%$ & $0.40 \pm 0.23 \mathrm{a}$ & $0.15 \pm 0.04 \mathrm{~b}$ & $0.23 \pm 0.04 \mathrm{~b}$ & $0.10 \pm 0.07 b$ \\
\hline OTU9 & Uncultured bacterium & AHN51493 & $100 \%$ & $1.42 \pm 1.14 \mathrm{a}$ & $0.34 \pm 0.14 \mathrm{~b}$ & $0.85 \pm 0.48 \mathrm{ab}$ & $0.35 \pm 0.17 b$ \\
\hline OTU10 & Skermanella stibiiresistens & WP037454648 & $99 \%$ & $2.05 \pm 0.64 \mathrm{a}$ & $0.64 \pm 0.17 \mathrm{~b}$ & $1.00 \pm 0.32 b$ & $0.42 \pm 0.24 \mathrm{~b}$ \\
\hline OTU13 & Bradyrhizobium sp. TUTMCJ4B & AKN21127 & $99 \%$ & $12.86 \pm 3.04 \mathrm{a}$ & $4.98 \pm 1.30 \mathrm{~b}$ & $7.19 \pm 2.08 \mathrm{~b}$ & $4.77 \pm 3.02 b$ \\
\hline OTU14 & Burkholderiales bacterium JOSHI_001 & WP009549047 & $99 \%$ & $1.20 \pm 0.22 \mathrm{a}$ & $0.71 \pm 0.34 \mathrm{~b}$ & $0.70 \pm 0.39 b$ & $0.42 \pm 0.22 b$ \\
\hline OTU16 & Azohydromonas lata & WP084268130 & $99 \%$ & $0.70 \pm 0.15 \mathrm{a}$ & $0.40 \pm 0.13 b c$ & $0.50 \pm 0.26 \mathrm{ab}$ & $0.16 \pm 0.09 \mathrm{c}$ \\
\hline OTU17 & Bradyrhizobium japonicum & $\mathrm{ABO} 27443$ & $100 \%$ & $63.01 \pm 1.22 \mathrm{c}$ & $86.59 \pm 2.22 \mathrm{a}$ & $81.73 \pm 0.94 b$ & $87.26 \pm 4.10 \mathrm{a}$ \\
\hline OTU26 & Skermanella stibiiresistens & WP037454648 & $99 \%$ & $0.34 \pm 0.06 \mathrm{a}$ & $0.10 \pm 0.05 b$ & $0.15 \pm 0.09 \mathrm{~b}$ & $0.07 \pm 0.07 \mathrm{~b}$ \\
\hline OTU30 & Skermanella stibiiresistens & WP037454648 & $97 \%$ & $2.30 \pm 0.69 \mathrm{a}$ & $0.68 \pm 0.14 b$ & $0.97 \pm 0.30 \mathrm{~b}$ & $0.48 \pm 0.30 \mathrm{~b}$ \\
\hline OTU31 & Skermanella stibiiresistens & WP037454648 & $99 \%$ & $3.41 \pm 0.87 \mathrm{a}$ & $0.83 \pm 0.17 \mathrm{~b}$ & $1.31 \pm 0.37 \mathrm{~b}$ & $0.68 \pm 0.49 b$ \\
\hline OTU32 & Burkholderiales bacterium JOSHI_001 & WP009549047 & $99 \%$ & $0.42 \pm 0.10 \mathrm{a}$ & $0.06 \pm 0.02 b$ & $0.07 \pm 0.04 b$ & $0.03 \pm 0.02 b$ \\
\hline OTU41 & Geobacter metallireducens & WP004514270 & $99 \%$ & $0.68 \pm 0.64 \mathrm{a}$ & $0.22 \pm 0.12 \mathrm{a}$ & $0.61 \pm 0.83 \mathrm{a}$ & $0.16 \pm 0.07 \mathrm{a}$ \\
\hline
\end{tabular}

3 Abbreviation for treatments as described in Table 1.

$4 \pm$ Different letters within the same row indicate significant difference systems samples tested by one-way ANOVA $(P<0.05)$. Values are the means \pm SE

$5 \quad(n=4)$. 